\title{
Success Factors of Hybrid Entrepreneurs: Case Study of Universitas Ciputra Academician
}

\author{
Febe Yuanita Ratna Indudewi
}

Universitas Ciputra; E-mail: febe.yuanita@ciputra.ac.id

\section{Doi:10.5901/mjss.2015.v6n5s5p84}

\begin{abstract}
Indonesian people show indication not having enough courage to be Entrepreneurs. Business owners account for less than 2 percents of the Indonesian population. Neighboring countries, such as Singapore and Malaysia, have much higher rates. One of the problems is a mentality problem. Fear of starting something new, lack of skills, and knowledge make most of Indonesian population choose to be employees. Yet as an employee, we have risk of being laid off. So there is an alternative transition phase labeled as Hybrid Entrepreneur to reduce risk as a business owner and as an employee. Thus, this study will try to see the supporting success factors both internal and external that enable someone to have a wage work while working on own business, and why they stay in this role. This study learn how hybrid entrepreneur able to perform their two roles, if the working environment suitable enough. This will be an exploratory research using qualitative data and case study. This research is interesting because of the informants and working environment characteristics. All of the informants are academicians who are running their own businesses with minimum 24 working hours per week as employees (lecturers in this case study).
\end{abstract}

Keywords: Hybrid Eentrepreneurship; Entrepreneurship; Self-employment; Employee

\section{Introduction}

According to forbes.com, the biggest risers in Entrepreneurship \& Opportunity in the last 6 years (2009-2014) are: Indonesia, Kazakhstan, and Vietnam. Improvement in the state of the entrepreneurial environment in Indonesia, have seen in infrastructure and access to opportunity. Indonesia has the highest perception of opportunity in the world at $99 \%$ believing working hard can get you ahead. This is a slight rise on 2009 (97\%) but within the margin of error. Since 2011, economic freedom in Indonesia has advanced by over 2.0 points, reflecting a more sustained commitment to opening up the financial sectors and improving the investment regime. However, Indonesia people showing indication not having enough courage to be Entrepreneur. Business owners account for less than 2 percent of the Indonesian population. Neighboring countries, such as Singapore and Malaysia, have much higher rates. One of the problems is a mentality problem. Courageous in taking risks for most Indonesia population is very low. Fear of starting something new, lack of skills, and knowledge make most of Indonesian population choose to be employees.

Burke et al. (2008) in Folta Research found that pure entrepreneurs are outnumbered by individuals who mix their time in both self-employment and wage work, and other scholars have described the prevalence of this phenomenon across multiple countries ${ }^{1}$. Indonesia is one of the countries that have this phenomenon. However, not all individuals who mix their time in both self-employment and wage work are hybrid entrepreneurs. An individual who has an additional wage work outside his own venture because of financial restrictions is not a hybrid entrepreneur. ${ }^{2}$ Joy (2009) thinks Hybrid entrepreneurship is the most advantageous way, in any kind of economy, to address financial challenges.

This research goal is to find out supporting factors that enables someone perform well in two roles as hybrid

\footnotetext{
1 Burke et al. (2008) followed 11,361 men and women from the British National Child Development Study and found that pure entrepreneurs were outnumbered by individuals who mixed their time in both self-employment and wage work. Evidence from the European Labour Force Survey indicates that a large proportion of the self-employed (11\% in Greece, 18\% in France, 32\% in Sweden, and $68 \%$ in the Netherlands) often combine self-employment with some other type of work (Strohmeyer and Tonoyan 2006). Renna (2006) recently noted that the incidence of dual jobholding is higher for the self-employed than for wage workers. A number of studies have noted that over $50 \%$ of nascent entrepreneurs are also employed full-time for pay (Reynolds et al. 2004, Petrova 2005, Campbell and De Nardi 2007), leading Reynolds, et al. (2004: 41) to note that hybrid entrepreneurship is-one of the least understood features of nascent entrepreneurs.

${ }^{2}$ Folta et al. (2010) conclude that individuals may enter hybrid entrepreneurship to generate non-monetary benefits, but found no indication that people become hybrids to earn supplemental income. Similar findings were reported by Petrova (2012), who concluded that part-time entrepreneurs are not impacted by financial constraints.
} 
entrepreneur: identifying internal and external factors that significantly empower this role. By analyzing the key success factors of hybrid entrepreneur; we can motivate more Indonesian people to be hybrid entrepreneurs for a better economic condition. Most of Indonesian people are still in part-time entrepreneurs phase, which is doing side job business out of financial restriction but they don't have the right entrepreneurial strategic phase to develop the business.

\section{Theoretical Frameworks}

\subsection{Hybrid Entrepreneur}

Joy (2009: 34) in her book defines hybrid entrepreneur as an individual that combines two ways of earning income: employment and entrepreneurship. So, hybrid entrepreneurship is literally the act of working a job while building a business. Folta et al. (2010: 253) describe hybrid entrepreneurship as a method that minimizes the personal risks and still allows the entrepreneur to take off with his or her venture gradually while still having a wage-work. A method that allows the individual to test the entrepreneurial entry and gain knowledge, skill, and experience during the start-up in order to learn about the ventures potential as well as the individuals own entrepreneurial characteristics and skills.

Folta et al. (2010) find hybrid entry influences self-employment entry but does not determine it. While according to Joy (2009), hybrid entrepreneur does not necessarily seek to become a full-time entrepreneur. ${ }^{3}$ Joy (2009) believes hybrid entrepreneur builds the business to a comfortable level of income and manageability and from there the hybrid entrepreneur focuses on continuing to do well on their job while providing exceptional service to a core group of customers in their business. Joy (2009) defines hybrid entrepreneurship as more than just a phase to be full-time entrepreneur. In her book, hybrid entrepreneurship lifestyle and philosophy trusted can shift the power and finances back to the middle class and small business owners.

\subsection{Success Factors}

In Driessen and Zwart research (2010: 4-5), the success of the entrepreneur can be defined in many ways. In most studies, success is defined as business continuity in the first two or three years. To become a successful entrepreneur, one must have an idea or a clear business vision, willingness and courage in the face of risk. If there is a readiness in the face of risk, the next step is to create a business plan, organize and run it. In addition to working hard, so that the attempt is successful, entrepreneurs must be able to develop good relationships with business partners or parties related to the interests of the company. This helps to validate the business success rate of the informant.

Suryana (2009: 67) suggests three factors causing the success of an entrepreneur, among others are ability and willingness, strong determination and hard work, and opportunities recognition. People who have the ability but do not have the will and the people who have the will but does not have the ability, they will not be successful entrepreneurs. People who do not have a strong determination but willing to work hard and people who do not want to work hard but have a strong determination, will not become successful entrepreneurs Recognize opportunity that exist and try to grab it is one of the factors that determine the success of an entrepreneur.

On the other hand, McClelland cited in Utami research (2007) classifies two factors that determine the success of entrepreneurs as internal and external factors. Internal factors include motivation, experience or knowledge, and personality. The success of the work requires motives for pushing or encouragement in the work. Motive is on the individual to have a passion or interest in meeting the needs and carry out tasks in the job. Meanwhile, the need for experience is the knowledge that should be sought as much as possible. Experience is knowledge or skill that must be mastered or known as a result of the actions that have been done before for a certain period. More experienced entrepreneurs keen in seeing more ways to open a new business. Good personality is when entrepreneurs can cooperate well and can adjust to the environment naturally and effectively.

External factors include family environment and workplace environment. Family circumstances can affect a person's success in starting a business. The tension in the family will decrease motivation and work to be disrupted.

\footnotetext{
${ }^{3}$ Felicia Joy is a nationally recognized entrepreneur, talk radio show host, business coach and investor who is frequently requested by major press outlets and various organizations to speak in plain language on the ins and outs of entrepreneurial success. Prior to becoming a full-time entrepreneur, Felicia built a successful career in Corporate America as a crisis management and communications executive, creating more than $\$ 50$ million in value for the organizations and companies she served before deciding to launch her own enterprises. She is author of Hybrid Entrepreneurship ${ }^{\mathrm{TM}}$ : How the Middle Class Can Beat the Slow Economy, Earn Extra Income and Reclaim the American Dream.Copyright (C) 2009
} 
Harmonious family environment in interaction will support the success and directing personnel to work more efficiently. Workplace environment has a significant influence in running the business. This environment can be classified into physical work situation and relationships with partners.

\section{Research Methods}

Based on type of problem under study and its objectives, this research will be using qualitative methods. The reason this research using qualitative method is because the issues to be addressed not with respect to numbers but describe clearly and in detail as well as obtain in-depth data from a research focus on the critical success factors of hybrid entrepreneur will be easier and more efficient. This study includes exploratory research. Exploratory research is one approach to research aimed at finding information about a topic or problem that is not yet fully understood by a researcher. Exploratory research tends to tackle new problems on which little or no previous research has been done (Brown, 2006, p. 43).

\subsection{Data}

Informants in qualitative research are closely associated with contextual factors to capture as much information from various sources and building. The goal is to specify that there is specificity in the context of a unique concoction. In accordance to Moleong (2010: 224), the purpose of informants as a qualitative research sample is purposive sampling (purposive sample). Purposive sampling including sample types of non-probability sampling, which does not provide equal opportunities to every object of research to be used as informants. In this study, a sample of informants is determined based on its own considerations are deemed to provide data according to the focus of research that could ultimately be deduced.

The uniqueness of the subjects in this study is that they are all lecturers at Universitas Ciputra and they all have businesses. Not many people can handle having two roles all at once. Hybrid entrepreneurs reduce risks as single role being employees or entrepreneurs, yet hybrid entrepreneur has its own risks that one of the roles might fail or must be sacrifice. On the basis of the uniqueness, the researchers took several informants as a sample to look at the factors that influence the success factors role as hybrid entrepreneur. Some of them have grown up in an entrepreneurial family, especially with an entrepreneurial father. Some of the others have grown up in non-entrepreneurial family.

The informants used in this study are lecturers at the Universitas Ciputra (UC) ${ }^{4}$ who have their own businesses in the past 2 years and still work at the Universitas Ciputra. The informants at least have a 24 hour per week contract with Universitas Ciputra. Research conducted is on five hybrid entrepreneurs who have certain characteristics. All five of these informants sign a contract and their names are parts of official lecturers in Universitas Ciputra. They all have records as employees but also run their own businesses. Five informants use code name $A B, A S, F, G W, M N$, with details as presented in Table 1.

Table 1. Hybrid Entrepreneur Informants

\begin{tabular}{cll}
\hline Name & Employee working hours & Business \\
\hline AB & Minimum 40 hours a week & Engine manufacture, Training center, and 3D printer and rapid prototype \\
AS & Minimum 40 hours a week & Webhosting \\
F & Minimum 40 hours a week & Printing store \\
GW & Minimum 24 hours a week & Sausage meatballs, Trading, Milk tea, Syrup, and Business consultant \\
MN & Minimum 40 hours a week & Design and architect consultant \\
\hline
\end{tabular}

There are several kinds of techniques to collect data used in this study such as interviews, observation, field notes, and documentation.

\footnotetext{
${ }^{4}$ University of Ciputra was founded within CitraLand, Surabaya, East Java, Indonesia. It is the first academic institution focusing on entrepreneurial education in Indonesia. Eventually, graduates from University of Ciputra are expected to be independent and highlyskilled individuals armed with an entrepreneurial spirit, paving his/her own way in becoming successful entrepreneurs. Different from other entrepreneurship programs, UC offers a complete entrepreneurship curriculum to its students. After graduating from a four-year program at Ciputra University, alumni will understand the principals of their business field and will benefit from that understanding.
} 


\subsection{Validity}

In this study, researcher applies the criteria of degree of confidence (credibility) that essentially replaces the concept of the internal validity of non-qualitative. Researchers conducted using the external transferability validity criterion. External validity is regarded to the degree of accuracy whether the results can be generalized or applied to a population in which the sample was drawn. In this case, the limitation of the data application on workers in academic and business environments that can be run with the help of technology and the internet.

For data reliability in qualitative research uses the criterion of dependability. Reliability of the data or findings occurs in the degree of consistency and stability. A reliable data is expressed when two or more researchers in the same object produces the same data or the same researchers in different time generating the same data, or group data when the data is broken down into two shows are no different.

\section{Results}

Once the data is obtained, the next step is the analysis of data. Bogdan and Biklen in Moleong (2010: 248) defines qualitative research data analysis as the efforts made by working with the data, organize data, sorted them into manageable units, synthesize, search and find patterns, find what is important and what is learn and decide what can be told to others. Analysis of the data according to Patton in Moleong (2010: 280) is the process of arranging the order of the data organizing them into a pattern, category, and basic unit of description. Data analysis was done at the time of collecting the data and after data collection. The data obtained from the research background is the raw data that must be processed in order to obtain a data ready to be served to be the result of a study.

In this study, researcher analyzes the data using Comparative Methods and Equipment (constant comparative method) proposed by Glases \& Strauss in Moleong (2010: 287). This method of data analysis constantly comparing one datum to another datum, then regularly compares each of categories. ${ }^{5}$

\subsection{Internal Factors}

Internal factor category comparison starts with motives. All of the informants agree that having two roles or becoming Hybrid Entrepreneurship giving them additional income. However, if they have to choose one role they are still able to live decent life. So it is not about monetary benefit. Some informants say it is passion, some say it is a "calling" that they decide to retain their status as employee and at the same time running their business. All of them passionate in education and the feeling in control of doing something they like in their business. This condition approve Folta et al. (2010) that conclude individuals who enter hybrid entrepreneurship generate non-monetary benefits, and find no indication that people become hybrids to earn supplemental income. All informants enjoy having their two roles. They hardly choose one role. $A B$ once said that these two roles what make him have a colorful life he needs. GW said, working as an employee fulfill his need in having human relation, that is why he cannot just have one role at one time. $M$ said it is her calling to share her knowledge, something that she meant to do and must do, so she can't just be an entrepreneur. Strong motives will keep hybrid entrepreneur stay as hybrid and try to perform well in both roles as hybrid entrepreneur.

On second internal factor category, experiences they gain when they grow up and while being entrepreneurship facilitator support them to perform in their business. Their hands on business experience then complement their ability to mentor their students. Eventually they have more confidence in delivering entrepreneurship concept to their students. Both job and business experience needs to relate to each other so they can keep their business success as part of the job (wage work) performance indicator. This will require them to perform well in both business and job performance.

Third internal factor category is skill. Here, we can describe their main skill that enable them retain their employee status while growing their business. At first, researcher thinks that it is about time management skill. Yet all of them agree its communication skill that enables them to perform their two roles as hybrid entrepreneur. Delegation skill, leadership skill, networking skill, negotiation skill, all comes down to one critical skill which is communication skill. AB and AS said it is about building system that enable them overcome time constraint, but it's not going to work well if they cannot communicate this system to their staff. GW said his main key successful factor at work as employee and as business owner is to build relationship, good relationship helps him control his businesses, and in order to build a good relationship he needs to develop communication skill. Since hybrid entrepreneur are most likely remote from their business, they need to be able to build the right system to make sure their business running while they are busy as a wage worker. And no

5 Categories and its comparison presented in tables 3 and 4. 
matter how good the system is, they need to be able to delegate the businesses.

Final internal category is personality. Researcher changes term "personality" with "behaviour character" because according to Ginsberg and Buchholtz in McNeil et al. (1991) ${ }^{6}$ research, their study review found that entrepreneurs were typically characterized by their behaviors more than by their personalities. $A B$ and $G W$ are risk takers and confidence. Both $A B$ and $G W$ have more than one business. GW always suggests non regular method in his role as an employee. $A B$ said "There's no hindrance that cannot be overcome. We just have to find the right system to solve the problem." He also chooses not to choose between his role as an employee and an entrepreneur because he believes he can perform these two roles. AS, F, dan MN are risk averse individuals and less confidence compare to $A B$ and GW. AS, F, and MN fit in the risk aversion individuals profiles that usually embodied by hybrid entrepreneurs. Researcher concludes each of this informant's character based on close observation by having close relationship with informants and by observing their performance in Universitas Ciputra. Researcher also compares their tone and body language as they being interviewed. However, researcher finds all of them are creative, adaptable, and open minded individuals in their area of discipline. They accept new knowledge and update them self as they all feel the needs of personal development in their life. This flexibility is the key factors of them to stay as hybrid entrepreneur and try their best to perform well as an entrepreneur and as an employee.

\subsection{External Factors}

First, we compare family roles in informant's life. All of them feel helped by their spouse. Their spouses complement their weaknesses when running business. Four out of five informants think they will still have their two roles as hybrid entrepreneurship. Only one informant said that he would not go extra mile having his own businesses if he is still single. However, related with the key skill to delegate the business, all of the informants securing their position by having their spouse as their business partner. In this case, I assume how important it is to have the right business partner to perform well in both job and business.

In terms of working physical situation and partners or co-workers are two categories to get insight of working environment factor. Universitas Ciputra is a workplace which supports and values entrepreneurship. Universitas Ciputra requires all lecturers to contribute and facilitate Entrepreneurship knowledge to the students. Physically, throughout Universitas Ciputra, we will hear students talking about their businesses and projects. There are no specific rules about lecturers cannot have their own business, as long as the main job responsibility as lecturers fulfilled. Another ethic code is not to have business or having personal involvement with the students, to maintain lecturers' integrity.

AS and F start their business because of Universitas Ciputra Entrepreneurial environment. $A B, M N$, and GW choose to join Universitas Ciputra and embrace their hybrid entrepreneurs' roles because Universitas Ciputra has the same value as their personal value. Will this happen if they are not at Universitas Ciputra? AB argues yes he still wants to be a hybrid entrepreneur, so are GW and MN as long as the workplace provides him with flexibility and supportive coworker. They already own business before they enter Universitas Ciputra. On the other hand, AS and F doubt they will be hybrid entrepreneurs if they are not working in workplace like Universitas Ciputra. Choosing the right working environment to work as an employee is the supporting factor for them to be able to perform well as a hybrid entrepreneur. If all the informants work as an employee in other business area and in different type of working environment, they will lack of motivation, and even if lecturing is the calling, they will choose not to be full time lectures.

In business, $A B$ and $G W$ certainly agree that their expanding businesses need good relationships with partner and staff. This is how GW controls his businesses remotely. $A B$ implements good relationship to know which man suitable in which position to expand his businesses. While AS, F, and MN also agree that working with the right and trustworthy partner and having good relationship with them is one of key successful factors that enable them having a peace of mind to work as employees and running businesses. Relationship with coworker and colleague is also a supporting factor to make them stay as hybrid entrepreneurs and able to work with less tension as employee.

Final external factor we discuss is technology factor. All of informants involved agree that technology support them in doing their two roles as hybrid entrepreneurs. They can work and control their business remotely. Technology enables

\footnotetext{
${ }^{6}$ Ari Ginsberg and Ann Buchholtz presented a study in the late 1980's that reviewed 10 earlier studies of the personality characteristics and traits of entrepreneurs, looking for common factors. People were considered entrepreneurs when they were founders of a distinct new venture who then took on the roles of owner and manager of the resulting business. Ginsberg and Buchholtz used these behavioral qualities to propose a two-dimensional framework for defining entrepreneurial styles. The first dimension combined risk-taking propensity with decision-making autonomy (independence), and the second one singled out innovation propensity (creativity). Ginsberg and Buchholtz (23) concluded their study by saying, "In light of the divergences reflected in the results, it could not be concluded that entrepreneurs are a different breed as far as personality characteristics are concerned."
} 
them to communicate with their partner, staff, and client or customers using emails, messengers, and phone line. Advance technology enables what cannot be done in years ago. Most likely all of these hybrid entrepreneurs perform well because they can work remotely using technology.

\section{Conclusion}

All of informants as hybrid entrepreneurs in this research sample agree that becoming successful hybrid entrepreneurs means their job as employees similar or cross path with their businesses. One role complements another role and vice versa. Hybrid entrepreneur requires the same knowledge, same passion or same discipline area or same expertise. One role also benefits another role and vice versa. Hybrid entrepreneurs must have passion in both of their job as employees and in their businesses. Hybrid entrepreneurs happen because of strong inner determination. Their ability to recognize opportunity pursues them in business as well as pursues their calling and passion as employees makes them unique individuals. Those who enter hybrid entrepreneurship appear to have risk preferences that are indistinguishable from those who remain in paid employment, but this study finds that those who have higher risks tolerances (risk takers) are able to grow their businesses and can handle more than one business while still retaining position as employees.

In order to sustaining and growing their businesses while performing role as good employee, external factors also become the key successful factor. Internal factors seem to be the critical cause to be hybrid entrepreneurs, but external factors support their performances. Good communication skill helps build relationship, networking, and recognize the opportunity. Building system and project managerial skill are also critical success factors before jumping into pool of work load by having two roles as employees and entrepreneurs at the same time. But finding the right business partner to delegate work load is important to perform the business. All of the informants in this research have spouses that handle some of their work, when they have to perform as employees. Spouses help them cover their weaknesses in business area. Supportive co-worker also supports hybrid entrepreneur so they can perform well as employee.

\section{Limitations and Further Works}

Hybrid entrepreneurship research is still very few, most of the researches conduct in Sweden. Another research should test the hybrid entrepreneur motives and external factors that can support hybrid entrepreneur emergence in Indonesia. This research is still limited to academician hybrid entrepreneur. It is the first research to understand how hybrid entrepreneurs work and identify factors that enable them to perform well as employees and entrepreneurs. Future research should use larger data from area outside academia, and compare the result to these research findings. Quantitative method to check these research findings will be useful too. Testing previous finding with different gender and business type implication can be another future work.

\section{References}

Brown, R. B. (2006). Doing Your Dissertation in Business and Management: The Reality of Research and Writing, Sage Publications

Driessen, M. P., \& Zwart, P. S. (2010). The Entrepreneur Scan Measuring Characteristics and Traits of Entrepreneurs. Retrieved from http://www.entrepreneurscan.co.uk/wp-content/uploads/2010/10/E-Scan-MAB-Article-UK.pdf

Folta, T. B., Delmar, F., and Wennberg, K. (2010). Hybrid Entrepreneurship, (825).

Hammarstrom, N., \& Nylen, V. (2014). "Pursuing Hybrid Entrepreneurship in Academia - A study about identifying influencing factors correlated to academic entrepreneurship". Umeå School of Business and Economics.

Joy, F. (2009). Hybrid Entrepreneurship TM (p. 185). Atlanta, Georgia: Joy Group International - Publishing Division.

McNeil, Ronald D., and Burgar, Paul S. (1991). Entrepreneurship Success or Failure: Can We Identify the Causes? Journal of Business and Entrepreneurship.

Moleong, Lexy J. (2005). Metodologi Penelitian Kualitatif. Bandung: Remaja Rosdakarya.

Raffiee, J., \& Feng, J. (2012). Should I Quit My Day Job? A Hybrid Path to Entrepreneurship. University of Wisconsin-Madison. Academy of Management Journal.

Riyanti, D. (2003). "Kewirausahaan Dari Sudut Pandang Psikologi Kepribadian”. Jakarta: PT. Grasindo.

Robert D. Hisrich and Michael P. Peters. (2002). Entrepreneurship, Fith Edition, Mc Graw-Hill.

Susah Nggak Sih Kerja Kantoran Sambil Bikin Bisnis Sendiri. (2014). Retrieved January 10, 2015, from http://www.vemale.com/ relationship/karier/59925-susah-nggak-sih-kerja-kantoran-sambil-bikin-bisnis-sendiri.html

Springer, Jon (2014). Legatum's 2014 Prosperity Index: Asia Positives For Entrepreneurship, Indonesia, Mongolia. From: http://www. forbes.com/sites/jonspringer/2014/11/14/legatums-2014-prosperity-index-asia-positives-for-entrepreneurship-indonesia-mongolia/

Utami, Erlita Diah (2007). "Faktor-Faktor Yang Mempengaruhi Minat Berwiraswasta (Studi Deskriptif Pada Usahawan Rental Komputer Di Sekaran Gunung Pati Semarang)". 
Zimmerman, M. A., \& Chu, H. M. (2013). "Motivation, Success, and Problems of Entrepreneurs in Venezuela". Journal of Management Policy and Practice, 14(2), 76-90.

Zulkifli. (2009). "Faktor-Faktor yang Mempengaruhi Keberhasilan dan Kegagalan Seorang Wirausaha Dihubungkan Dengan Pemilihan Bidang Usaha". Jurnal Ekonomi, 28-33. 